\title{
On the Commercial Utilization of Right of Habitation
}

\author{
Tong Zhou \\ Wuhan University, Wuhan, Hubei 430072, China
}

\begin{abstract}
The introduction of the "right of habitation" is a bright spot in the Civil Code of the People's Republic of China, but it has not broken through the traditional attribute of personal servitude and excluded the commercial use. From the historical evolution and realistic demand of the right of habitation, this choice of the function does not meet the needs of our market economy and the development of modern society. Therefore, from the right attribute and functional shift of the right of habitation, this paper holds that the right of habitation has the possibility of commercial use. But to strike a balance between the diversified needs of market players and the unique nature of the right of habitation system, the commercial utilization of right of habitation shall have an appropriate scope of application, and limit the scope of holders to natural persons.
\end{abstract}

Keywords: Right of Habitation; Personal Servitude; Commercial Utilization.

\section{Raising the Problem}

The right of habitation is a bright spot in the Civil Code, which has aroused widespread concern from all walks of life. In fact, the right of habitation was considered to be introduced as early as 2002, when the Real Right Law was enacted. But at that time, it was thought that the right of habitation mostly occurred between relatives and friends, it can be settled by the law of contract, marriage and family, etc., and need not be established as the type of real right, so it was not introduced in legislation. [1] But with the development of economy and the rising of real estate prices, the claims of the right of habitation are increasing. According to the statistics, the number of cases of right of habitation is increasing year by year, and the cases of it are more than those in the field of marriage, family and inheritance. There was no explicit legal support regarding right of habitation before the promulgation of the Civil Code, remedies for disputes over right of habitation in judicial cases mainly included protection via public order and good customs, protection from the perspective of real right, and protection from the perspective of creditor's right. In terms of the logic and coordination of legal interpretation, there is no doubt that these remedies have certain drawbacks. [2] In practice, the people have spontaneously created the right in the areas such as sale, raising funds, donations, etc., and even judges may infer the existence of the right for the parties who do not explicitly set it. [3] The dispute of the right of habitation belongs to the dispute of property right in essence, The increasing number of the dispute of the right of habitation needs a more perfect system to regulate it. The disputes of the right of habitation are essentially real rights disputes, and the increasing number of the disputes requires a more complete system of the Real Right Law to regulate them. Hence, in response to the demand of practice, the system of the right of habitation is introduced in the Civil Code.

Under the social background of aging population and shortage of housing, the system of right of habitation can adjust the housing problem of the surviving spouse in old age, divorce and widowhood, and has incomparable advantages to other systems in achieving the goal of "having a place to live". [4] However, the current system of right of habitation in China has not broken through the shackles of "personal servitude". It only focuses on its guarantee function and excludes its commercial use. With the development of market economy, it is necessary for the system of right of habitation to comply with the law of market economy, and change to the diversified use of property. Therefore, this paper takes the commercial utilization of habitation right as the object of study, analyzes the possibility of the commercial utilization of habitation right from the attribute of habitation right, and tries to establish a legal framework for the commercial utilization of habitation right to meet the diversified needs of different market subjects. 


\section{The Right Attribute and Functional Shift of the Right of Habitation}

\subsection{The Right Attribute and Functional Shift of the Right of Habitation}

The right of habitation was created in ancient Rome to protect the living interests of the family members who did not have a house. Under this background, the right of habitation has obvious personalty of servitude and security. The subjects of rights are based on the identity and, further, nonassignment, non-succession and other identity contents are derived. Accordingly, the early right of habitation, which was characterized by personal servitude, paid more attention to the security and humanistic care of family members.[5]

With the development of economy, when the European civil codes inherited the right of habitation system, it began to break through the character of personal servitude, and to develop to multiple uses of property. For example, article 980 of the Italian Civil Code provides that the usufructuary has the right to transfer his right if there are no prohibitive provisions at the time of establishment. The German Law of Ownership and Long-term habitation in 1951 and the Law of Time Division of habitation in 1957 establish the right of habitation which is different from the traditional pure real right. Article 628 of the French Civil Code changes the mode of establishing the right of habitation from the mode of establishment of bequest to that of contract, which is the basic mode of establishment.

It can be seen that the right of habitation has undergone a process from the weak family members to the general property owners, and its function has evolved from the protection of the weak to the multi-use of the property.[5] Therefore, some scholars believe that the right of habitation can get rid of the attribute of personal servitude and form its own system. [2] Under the background of marketization, perhaps we should re-examine the attribute and function of the right of habitation, and make a more appropriate choice.

\subsection{Choice of Function of the Right of Habitation in the Civil Code}

In the process of compiling the Civil Code, there are two opposite viewpoints on the function choice of the right of habitation. The first viewpoint is that the purpose of introducing the right of habitation in China is to realize the special social groups' wish to have a place to live. It should stick to the attribute of personal servitude and pay attention to the security of the right of habitation. Therefore, the right of habitation should be established as non-transferable, non-burden-setting, noninheritable, free in principle and other legal structures. This is also a response to the requirement put forward in the report of the 19th National Congress of the Communist Party of "accelerating the establishment of a housing system that ensures supply through multiple sources, provides housing support through multiple channels, and encourages both renting and purchase, so as to enable all people to have proper places to live". [6] The second view holds that the essence of the right of habitation is the pluralistic use of houses under the separation of ownership and use rights. It is necessary to focus on the usufruct of houses, break through the personal servitude on the right of habitation, and take its legal features as its voluntariness, compensation and mobility, so as to make the right of habitation have a wider scope of application and meet the various needs of social life. Scholars who insist on this point of view further believe that the establishment of the right of habitation is to establish a buffer zone for the realization of property ownership and property utilization, and its essential characteristic is the separation of the two rights of housing ownership and the right of use; the personal servitude is the result of the projection of certain social base on the right, but under the condition that the economic base has changed, the personal servitude is no longer fit for the need of modern society.[5] [7]

Finally, the right of habitation is identified as a voluntary real right in the Civil Code, but its holder is strictly restricted when exercising such real right. The article 366, 368 and 369 of the Civil Code respectively prescribe the typical characteristics of the right of habitation as "meeting the needs of living", "gratuitous" and "non-transferable". That's mean, from the point of view of subject and object, the part of real right still upholds the personal servitude of "right of habitation", and constructs it on 
the basis of social right of habitation. [8] That is to say, in the legislation of China, the choice of function of right of habitation tends to guarantee function.

\subsection{Discussion on the Paid Nature of the Right of Habitation}

The paid nature of the right of habitation is closely related to its commercial utilization. In the process of establishing the right of habitation, there are many disputes about its attribute and function. Although the legislation denies the paid nature of the right of habitation and insists on the personal servitude, some scholars point out that it is obviously not appropriate. They think that the right of habitation should be applicable to a wider range of fields to meet the diverse needs of people for housing use. In addition to the traditional right of habitation in the field of marriage, family and inheritance, the right of habitation in the field of social security, investment and consumption can not be ignored.[2] Some scholars think that the proviso clause in article 368 of Civil Code provides the basis for the commercialization of the right of habitation. Some scholars believe that if the purpose of the right of habitation in article 366 of the Civil Code is to "satisfy the needs of life", so as to include the "needs for vacations", and allow the right of habitation to be set according to different time periods. Then the right of habitation can play the function of timeshare ownership in the comparative law, [9] which provides the possibility for the commercial utilization of the right of habitation.

The author believes that we can not completely deny the paid nature of the right of habitation, whether from the historical evolution or from the realistic demand. In the world, getting rid of the personal servitude of the right of habitation and widening the functional scope of it is the developing trend of legislation in many countries. From the reality, if the right of habitation is gratuitous, it can only be applied to the traditional domain of marriage, family and inheritance, and its scope of application will be limited. It is difficult to meet the diversified needs of the market subjects and the efficient allocation of resources and will not conform to the law of the development of market economy and modern society.

\section{Legal Construction of the Commercialization of Right of Habitation}

\subsection{Scope of Application of the Commercialization of Right of Habitation}

\subsubsection{Four Types of Right of Habitation}

As for the applicable scope of the right of habitation, it can be divided into four types: family security, social security, investment and consumption. Family security right of habitation is the most traditional type, which mainly applies to the field of marriage, family and inheritance, still retains the background of personal servitude, and undertakes the basic function of family life. In the field of marriage and family, the right of habitation mainly applies to the case of separation or divorce. When one of the spouses is in a state of separation or divorce, the right of habitation should be guaranteed so as to meet the needs of the weak party in the marriage. [2] In the field of inheritance, the right of habitation mainly protects the rights of the decedent and other non- heirs. For the decedent, before the ownership of the house is transferred to the heirs or legatees, they can sell the house to obtain the living expenses, at the same time set up the right of habitation for themselves, protect their right to live in the house. For other non-inheritors, the establishment of right of habitation provides a better solution to estate distribution. Setting the right of habitation for a specific person enables such person to have proper place to live while the inheritor's right to inheritance is guaranteed.[9]

Social security habitation right is a certain preferential treatment based on the ethical basis of social security for special social groups such as low-income families and special talents. These include national housing project housing, affordable housing, low-rent housing, public rental housing, housing reform housing, resettlement housing for demolition or shantytown renovation, resettlement housing for employees, talent placement houses (or talent apartments)etc.[9] Although China has provided housing for social vulnerable groups through affordable housing, two limited housing and 
security housing, these forms also have many disadvantages, such as high price, prone to speculation and limited supply, which can not meet the housing needs of people with lower income. After the introduction of the right of habitation, establishing it for the social vulnerable groups can become another form for the government to play the payment function. This form is conducive to avoid the disadvantages of the current social security, so as to realize the sharing of housing property rights and let the social vulnerable groups have their own houses.

While the investment and consumption habitation right realizes its function transmutation toward usufruct. Since most of the parties involved in investment-oriented residential rights are natural persons who have no housing difficulties and may even own other houses, investment is the primary purpose for the establishment of the residential rights, and investment may be applied to the cooperative construction of houses, purchase of houses through joint venture and cooperative development of houses. Most of the consumer right of habitation are enterprises, and the investors are managers, who provide living services for other natural persons, which are common in timelimited hotels, serviced apartments and long-term rental apartments. [2] Investment and consumption right of habitation break through the limitation of traditional personal servitude on different levels, and help to make the best use of housing and meet the needs of multi-use of buildings.

\subsubsection{Limitation of the Scope of Application of the Right of Habitation}

Against the background that China's housing social security system is still imperfect, the development of the commercialization of right of habitation shall be limited to a certain extent, promoted gradually and shall not be over-extended. First of all, based on the above classification, the family security habitation right and the social security habitation right belong to the basic security habitation. However, in terms of the social security habitation right, the paid establishment at a low price shall be taken into account to enable the establishment of the social security habitation right to be more flexible and further play to the payment function of the government. Secondly, the investment habitation right and consumption habitation right that break the personal servitude restrictions should be treated differently. The author support to recognize consumption habitation right first, and then consider the further development of the investment habitation right. On one hand, from the perspective of subjects, the parties concerned with consumption habitation right are mostly enterprises or organizations which are entitled to provide services only upon registration, which will facilitate national and societal regulation; but the parties concerned with investment habitation right are mostly natural persons who create the residential right for the purpose of investment, which poses relatively great risks. On the other hand, from the point of view of aim, the consumer right of habitation can provide a new kind of housing mode for consumers, which is in accord with the legislative aim of habitation. Although investment habitation right can achieve the purpose of making the best use of housing, it is more likely to cause disorder in the current situation that China's housing system is still imperfect. It is likely to lead to the accumulation of housing to a small number of investors and exacerbate the shortage of housing in China, which is in conflict with the legislative purpose of China's residential right.

Therefore, the authors believe that restrictions on the establishment of consumption habitation right can be relaxed appropriately to allow its existence. In the meantime, we should hold a wait-andsee attitude towards investment habitation right until further considerations are made as the society develops and the housing system improves.

\subsection{Restrictions on the Subjects of the Commercialization of Right of Habitation}

\subsubsection{The Subject Scope of Holders of the Right of Habitation}

During the process of compiling the Civil Code, different scholars have different views on the subject scope of the holders of the right of habitation. One view holds that any natural person, legal person or unincorporated association is entitled to the right of habitation and thus becomes the holder of the right of habitation. [10] Another view is that the holders can only be natural person.[11] According to the stipulations of the Civil Code, the object of the right of habitation in China is limited 
to "habitation" and its aim is "to meet the needs of living and dwelling", so we can infer that the right of habitation in China is limited to natural person. Based on this, some scholars analyze from the theory of civil rights and believe that certain civil rights to which a civil subject is entitled may be exercised by him/herself or by others on his/her behalf. Therefore, although a legal person or an unincorporated association cannot become the holder of the right of habitation, it does not deny that it may become a subject establishing the right. [12]

In this regard, the author believes that the right of habitation is limited to the natural person, but the legal person and the non-legal person organization can be the subject establishing the right. On the one hand, compared with natural persons, legal persons and unincorporated associations have strong funds and take more risks. If the scope of subjects of habitation right is expanded to include legal persons and unincorporated associations, the boundaries of their rights are hard to limit. Against the background that China's housing system is still imperfect, blindly extending the scope of holders who have the right of habitation to include legal persons and non-legal person organizations may further lead to the spread of "real estate speculation" and other phenomena. Limiting holders of right of habitation to natural persons is in line with the original intention of the system of introducing right of habitation in China. On the other hand, if legal persons and unincorporated organizations are the subjects who establish habitation rights, the act of establishment becomes valid upon registration, the state's supervision over the establishing subjects through registration may, to a large extent, prevent the occurrence of above mentioned risks. Therefore, a legal person or an unincorporated association may not be the holder of the right of habitation, but it may serve as a subject for the establishment of a habitation right.

Under the background of commercial utilization of habitation right, the author supports breaking through the limitation of personal servitude, recognizing the paid nature of habitation right, and developing consumption habitation right, which is mostly set up by enterprises for consumers in their apartments or hotels. Thus, through the way of interpretation, the establishment of the right of habitation can be a legal person, a legal person organization, to provide a theoretical basis for the development of the right of habitation.

\subsubsection{Scope of Holders of the Right of Habitation}

There are also two different views in academic circles on the determination of the cohabitant status of the right holder. One opinion holds that persons living together with the right holders shall be called holders of the right of habitation, while another opinion holds that a distinction shall be made between right holders and cohabitants. They insist that the right holder is the party who enjoys the right of habitation, while the cohabitant is the family member of the right holder or a person providing medical or housekeeping services, so he/she is the indirect beneficiary of the right of habitation.[12] The author prefer the second view, that is, to distinguish between right holders and cohabitants. The right holder shall be only the inheritor, the party who concludes a contract with the owner or the person who enjoys the right to live in the house in accordance with the judgment of the court. People who live together with the right holder such as the spouse, relatives, caregivers and nannies shall not naturally be right holders but only the beneficiaries of the right to live in the house.

The distinction between right holders and and cohabitants helps to determine the ownership of rights and facilitates the solution of relevant legal issues. However, in practice, it is likely that right holders exist in name while cohabitants actually enjoy the right of habitation. Such a case deviates from the original purpose of establishing the right of habitation to a certain extent. In the process of commercial development of the right of habitation, this phenomenon will increase undoubtedly, and may even lead to the risk of the right of habitation using legal gaps to speculate in real estate. Therefore, it shall be determined that the right of habitation is obtained through registration and both right holders and cohabitants shall enjoy the right to live in. But the rights of the cohabitant are subordinate to the holder of right of habitation. When the rights of the holder of right of habitation are terminated, cohabitants shall no longer enjoy the right to live in. 


\section{Conclusion}

The introduction of the "right of habitation" is a great progress in our civil legislation. It responds to the social needs and is beneficial to the realization of the goal of "having a place to live". But the right of habitation in China still retains its attribute of personal servitude and attaches importance to the choice of guarantee function, which is not in accordance with the law of market economy and the development of modern society. Therefore, it is the only way to promote the development of the right of habitation and make full use of its advantages to explore the commercial use of the right of habitation. Accordingly, in view of the social background that our housing system is still imperfect, in order to maintain the stability of the social order, the commercialization of right of habitation shall be explored step by step. Consumption habitation right may be developed first and investment habitation right may be temporarily maintained and further developed with the development of society and the improvement of the housing system in China. For the purpose of developing consumption habitation right, the interpretation on the subjects who establish the right can be expanded, allowing legal persons and unincorporated associations to exist as the subjects who establish the right of habitation, provided that such legal persons and unincorporated associations cannot become the holders of the right of habitation. Analogous to lease rights, the scope of the persons who enjoy the right to live in includes right holders and and cohabitants, but cohabitants are subordinate to the holder of the habitation right. When the rights of the holder of right of habitation are terminated, the rights of cohabitants shall be terminated.

To sum up, as a new system, the right of habitation in our country still has a lot of room for improvement. But it is undeniable that the right of habitation should not be confined under the yoke of "personal servitude". It should comply with the development of market economy and explore various possibilities of commercial utilization of the right of habitation.

\section{References}

[1] Compiled by the Civil Law Office of the Legal Work Committee of the Standing Committee of the National People's Congress: "The Legislative Background and Viewpoints of the Property Law", Law Press, 2007 edition, p. 49.

[2] Zeng Dapeng; "The Judicial Dilemma, Function Evolution and Legislative Reconstruction of the Right of Residence", published in "Science of Law", Issue 12, 2019.

[3] Xiao Jun: "How "Residence" Becomes a Kind of Property Right: From Roman Law Tradition to Contemporary Chinese Residence Right Legislation", published in "Science of Law (Journal of Northwest University of Political Science and Law)" No. 3, 2019.

[4] Gu Mingan and Jiang Shengyang: "The Necessity and Institutional Structure of the Establishment of Residential Rights in my country's Civil Code", published in Journal of Southwest University for Nationalities (Humanities and Social Sciences Edition), Issue 2, 2020.

[5] Lu Xiaoming: "The Positioning and Rule Design of the "Right of Residence"'", published in "Chinese Law" Issue 3, 2019.

[6] Chen Huabin: "The Construction of the Human Servant System-Concurrently Discussing the Regulations on the Right of Residence in the "Draft of the Civil Code", in "Comparative Law Research", Issue 2, 2019.

[7] Wang Liming: "Revision and Improvement of the Property Rights of Our Civil Code", published in "Academic Monthly", Issue 7, 2019.

[8] Tan Qiping and Fu Yiyao: "The System of the Right of Residence in the Civil Code and Its Realization Path", published in "Jiangxi Social Sciences" Issue 12, 2020.

[9] Xi Zhiguo: "Analysis of the Legal Doctrine of Right of Residence", published in "Nanjing Social Sciences", Issue 9, 2020.

[10] Shen Weixing and Yang Xu: How should the Chinese Civil Code stipulate the right of residence?, in "Comparative Law Research", Issue 6, 2019.

[11] Wang Liming: "On Several Issues of Residence Right in the Property Rights of the Civil Code", published in "Academic Monthly", Issue 7, 2019. 
Volume 15 (2021)

[12] Fang Shaokun: "On the Right of Residence in the Civil Code", published in "Modern Law", Issue 4, 2020. 